Committee is in broad agreement with the Parliamentary and Scientific Committee's recommendations as to matters for further research. Questions of fuel efficiency and the building programme of the Department of Scientific and Industrial Research were also raised in Parliament during the year.

\section{Society for Analytical Chemistry}

THE eighty-first annual general meeting of the Society for Analytical Chemistry was held in London on March 4, when the financial statement and the report of the Council for the past year were submitted and approved. The membership of the Society was reported as being 1,799-an increase of 153 since last year. In addition to five ordinary meetings in London (two of which were organized by the Biological Methods Group and one by the Microchemistry Group), a joint meeting with the Oils and Fats Group of the Society of Chemical Industry, and twenty-one meetings held by the Society's various Sections and Groups, the Society organized two special meetings in London as follows: one on the use of perchloric acid in analytical chemistry, at which a paper was read by Prof. Harold Burton and Dr. P. F. G. Praill, and one by Prof. G. Frederick Smith (University of Illinois); and the other, at which Prof. G. Schwarzenbach (University of Zurich) spoke on the complexones and their analytical applications, and Dr. H. M. N. H. Irving gave demonstrations.

At the annual general meeting of the Society the following officers and members of Council were elected for the forthcoming year : President, K. A. Williams; Past Presidents serving on the Council, Lewis Eynon, D. W. Kent-Jones, J. R. Nicholls and George Taylor; Vice-Presidents, C. A. Adams, D. C. Garratt and H. M. N. H. Irving; Honorary Treasurer, J. H. Hamence ; Honorary Secretary, N. L. Allport; Other Members of Council, D. C. M. Adamson, C. H. R. Gentry, J. Haslam, C. L. Hinton, W. C. Johnson, A. G. J. Lipscomb, T. McLachlan, R. F. Milton, Miss Mamie Olliver, S. A. Price, R. E. Stuckey and C. Whalley; Ex-officio Members, J. R. Walmsley (chairman, North of England Section), F. J. Elliott (chairman, Scottish Section), H. J. Evans (chairman, Western Section), J. R. Leech (chairman, Midlands Section), G. F. Hodsman (chairman, Microchemistry Group), A. A. Smales (chairman, Physical Methods Group) and L. J. Harris (chairman, Biological Methods Group).

\section{Models of Molecular Structure}

MANY research workers have been aware of the value of the space-filling atomic models developed by G. S. Hartley and C. Robinson at the Maidenhead Laboratory of Courtaulds, Ltd. These models are now available commercially from the firm of Griffin and Tatlock (Kemble Street, Kingsway, London, W.C.2). Primarily designed for research, where accurately made models are required from which quantitative deductions of molecular geometry can be made, the models are also eminently suitable for lecturing purposes. Their large size (scale $0 \cdot 8$ in. to 1 A.) and comparative 'transparency' make even complicated structures easy to follow. The bond angles, covalent radii and van der Waals radii of the atom models are based on currently accepted values. When the arrangement involves only $\delta$-bonds the models are designed by cutting back spheres, of radii equal to the van der Waals radii, in the direction of each valency bond, by an amount which leaves the distance from the atom centre to the middle of the link equal to the appropriate covalent radius. For those atoms forming bonds involving $\pi$-electrons, the van der Waals radius will be longer in a direction normal to the bonds as a consequence of the $\pi$-electron orbitals. Account has been taken of this factor. A notable feature of the design is the arrangement of brass link and rubber collar by which the models are joined together. This provides elastically distortable valency angles so that many molecules can be built, including those with strained rings, which cannot be constructed with a rigid linking mechanism. At the same time there is no sacrifice of free rotation about single bonds, while large molecules can be handled without falling apart. Important contributions to peptide and protein chemistry have already been made with the aid of these models. It is likely that their application in other fields will be equally fruitful.

\section{Indian Council of Ecological Research}

IN order to promote and expand ecological studiiss on Indian vegetation, an Indian Council of Ecological Research has recently been set up and will hold its first meeting at the Forest Research Institute, Dehra Dun, later this year, when plans will be made for the execution of ecologieal studies in relation to forestry, agriculture, desert control, soil conservation, flood control, etc. The heads of forest departments of all States of the Union and vice-chancellors of all Indian universities have been requested to send a note describing the type of ecological research at present being conducted and whether they will be able to participate in the work of the Council. With the information so collected, the Council will select places for the setting up of small experimentel stations for ecological research in collaboration with a particular university or State forest and agricultural departments. The Council also expects to arrange at Dehra Dun a short course in techniques and methods in ecological research for students, teachers and other workers engaged in ecological research. The Council consists of the following officers together with twelve members : Chairman, Shri C. R. Ranganathan, inspector-general of forests, New Delhi ; Vice-Chairmen, Shri K. L. Aggarwal, president of the Forest Research Institute and Colleges, Dehra Dun; and Father Santapau, chief botanist, Botanical Survey of India, Calcutta; Secretary, Dr. G. S. Puri, ecologist, Forest Research Institute, Dehra Dun. All inquiries should be directed to the secretary at P.O. New Forest, Dehra Dun, U.P.

\section{Pectic Enzymes}

IN a further contribution to the physiology of parasitism, R. K. S. Wood (Ann. Bot., N.S., 19, 1 ; 1955) has investigated the pectic enzymes secreted by Bacterium aroideae. $\mathrm{He}$ has shown that cell-free filtrates from cultures of this organism on a simple synthetic medium contained an enzyme, that he has provisionally called 'depolymerase', which has the property of reducing rapidly the viscosity of pectin solutions. The filtrate also contained protopectinase which macerated slices of potato tuber. The filtrates, however, had little pectin-esterase activity. The activity of the depolymerase was found to be directly proportional to the enzyme concentration; that of the protopectinase was approximately proportional to the square root of the enzyme concentration. Partial purification of crude solutions was effected by acetone or ethanol precipitation. The various 